\title{
Effects of Intratympanic Steroid on Cisplatin Ototoxicity: An Electrophysiological and Ultrastructural Study
}

\author{
Abdullah TAS ${ }^{1}$, Erdogan BULUT ${ }^{2,3}$, Memduha TAS $^{2}$, Recep YAGIZ ${ }^{1}$, Pinar TURAN ${ }^{4}$, \\ Aydın HUSEYINOGLU ${ }^{5}$, Ahmet R. KARASALIHOGLU ${ }^{1}$ \\ ${ }^{1}$ Trakya University Faculty of Medicine, Department of Otorhinolaryngology, Edirne \\ ${ }^{2}$ Trakya University Faculty of Health Sciences, Department of Audiology, Edirne \\ ${ }^{3}$ Trakya University Faculty of Medicine, Department of Physiology Edirne \\ ${ }^{4}$ Marmara University Faculty of Medicine, Department of Histology and Embryology, Istanbul. \\ ${ }^{5}$ Ağrı State Hospital, Department of Otorhinolaryngology, Ağrı, TURKEY
}

\begin{abstract}
Ototoxicity refers to the inner ear dysfunction caused by a drug or a chemical agent which manifests as hearing loss or balance impairment, or both. Currently, antibiotics, diuretics, anti-inflammatory drugs, antineoplastic agents, antimalarial drugs and some other agents are known to cause ototoxicity. Cisplatin is an antineoplastic agent for which the ototoxicity incidence may vary based on the treatment protocol. In the present study, we aimed to perform an electrophysiological and ultrastructural evaluation regarding the protective effectiveness of intratympanic steroids on cisplatin ototoxicity. Electrophysiological assessment included tympanometry and auditory brainstem response (ABR), and 16 guinea pigs (32 ears) with normal hearing were randomly assigned to 4 groups as follows: control, cisplatin, cisplatin/steroid and cisplatin/physiological saline. Following the electrophysiological measurements, temporal bones were dissected for ultrastructural examinations. In the cisplatin group, a statistically significant $(p<0.05)$ threshold difference was noted for the ABR test versus the other groups while this threshold difference was lower in the cisplatin/steroid group compared to the other groups. Ultrastructural evaluations revealed abnormal outer hair cell stereocilia morphology and severe degenerative changes in the cisplatin and cisplatin/physiological saline groups. Mild degenerative alterations were seen in the outer hair cell stereocilia morphology in the guinea pig cochlea administered with intratympanic steroid. We believe intratympanic steroid administration showed protective effectiveness on the cisplatin-induced ototoxic damage in our study.
\end{abstract}

Keywords: Cisplatin, Electron microscopy, Auditory evoked brainstem responses, Methylprednisolone

ÖZET

Cisplatin Ototoksisitesinde İntratimpanik Steroid Etkinliği: Elektrofizyolojik ve Ultrastruktürel bir Çalışma

Ototoksisite, bir ilacın ya da kimyasal ajanın, işitme kaybı, denge bozukluğu ya da her iki semptomu birden ortaya çıkaracak şekilde iç kulak disfonksiyonuna neden olmasıdır. Günümüzde antibiyotikler, diüretikler, antienflamatuarlar, antineoplastik ajanlar, antimalaryal ilaçlar ve diğer bazı ilaçların ototoksisiteye neden olduğu bilinmektedir. Cisplatinin tedavi protokollerine bağlı olarak ototoksisite insidansı değişiklik gösteren antineoplastik bir ajandır. Bu amaçla çalışmamızda, cisplatin ototoksisitesi üzerinde intratimpanik steroid uygulamaların koruyucu etkinliğini elektrofizyolojik ve ultrastuktürel olarak değerlendirdik. Elektrofizyolojik değerlendirmeye timpanometri ve işitsel beyinsapı yanıtları (ABR) dahil edildi ve işitmesi normal olarak değerlendirilen 16 kobay (32 kulak) kontrol, cisplatin, cisplatin/stereoid ve cisplatin/serum fizyolojik grupları olmak üzere rastgele olarak 4 gruba ayrıldı. Elektrofizyolojik ölçümler sonrası ultrastruktürel incelemeler için temporal kemikler disseke edildi. Cisplatin grubunda, diğer gruplara göre ABR testinde istatistiksel olarak anlamlı derecede eșik farklıı̆ı ( $p<0.05)$ bulunur iken bu eșik farkllığı cisplatin/stereoid grubunda diğer gruplara göre daha düşük elde edildi. Ultrastrukturel değerlendirmelerde ise cisplatin ve cisplatin/serum fizyolojik gruplarında anormal dış tüylü hücre stereosilya morfolojisi ve ağır dejenaratif değişiklikler gözlendi. İntratimpanik steroid uygulama yapılan kobay koklearında ise dış tüylü hücre stereosilya morfolojosinde hafif derecede dejenaratif değişiklikler gözlendi. Çalışmamızda cisplatine bağlı ototoksik hasarda intratimpanik stereoid uygulamaların koruyucu etkinliği olduğunu düşünmekteyiz.

Anahtar Kelimeler: Cisplatin, Elektron mikroskobi, İsitsel uyarılı beyinsapı yanıtları, Metilprednizolon 


\section{INTRODUCTION}

Ototoxicity is a common term for the defects seen in cochlear and vestibular organs following the interaction with various therapeutic agents and chemicals. ${ }^{1-3}$ The criterion to determine that a culprit medicine is actually ototoxic is as follows: if a substance has bilaterally caused at least a $10 \mathrm{~dB}$ loss between the frequencies of 250 and 8000 , this substance is deemed ototoxic; however, these frequencies may be higher at first involvements with agents such as aminoglycoside and cisplatin. ${ }^{3}$ Cis-dichlorodiammineplatinum II, known as cisplatin, is a potent antineoplastic agent used for the treatment of various malignant tumours such as ovarian, testicular, bladder, liver, head and neck cancers. ${ }^{4}$ Cisplatin is a broad-spectrum, platinumderived organic chemotherapeutic agent which is not period-specific. Chloride and ammonium are present in cis position at the central domain of the platinum atom. ${ }^{5,6}$ Only the cis isomer is cytotoxic. 6 Cisplatin exerts its therapeutic effect by forming cross-links between DNA double strands as well as inter-strand links. This leads to inhibition of DNA synthesis and transcription, and the cell cannot divide. Binding to DNA and cytoplasmic proteins may result in cytotoxic effects. This effect is considerably important for cellular toxicity. ${ }^{4,6,7}$ Cisplatin ototoxicity manifests as tinnitus, dizziness and hearing loss in clinical practice. This hearing loss is a permanent, progressive and a sensoryneural type hearing loss that moves through lower frequencies over time while it involves only high frequencies initially. 8 Primary target cells of cisplatin ototoxicity are the outer hair cells (OHCs), which are more marked in basal turns of cochlea. ${ }^{7}$ Corticosteroids are among the most commonly used medicines due to their anti-inflammatory, antiallergic and immunosuppressive effects..$^{9,10}$ The inhibition of inflammation by autoimmune dysfunction through the immune or direct effects of steroids on inner ear neuroepithelium may be the expected benefits of using corticosteroids in inner ear disorders. ${ }^{11,12}$ Glucocorticoids (dexamethasone, prednisone, methylprednisolone etc.) constitute a potential drug class with protective effectiveness against ototoxicity. Furthermore, systemic glucocorticoids are used for the treatment of hearing loss when the aetiology is unknown in cochlear conditions such as idiopathic hearing loss, tinnitus, Meniere's Disease, endolymphatic hydrops and autoimmune inner ear disorders. ${ }^{11-13}$ Corticosteroids have been shown to limit reactive oxygen species in the inner ear. ${ }^{14}$ Experimental studies have demonstrated protective effects of corticosteroids in aminoglycoside-induced ototoxicity, which is thought to have a similar pathogenesis to that of cisplatin-induced ototoxicity ${ }^{15,16}$, and the presence of corticosteroid receptors in inner ear structures suggests that steroids may have various effects in the inner ear. ${ }^{17}$ Proposed mechanisms of action include the notion that steroids administered to the middle ear vestibule move through the round window, improve cellular oedema and metabolic disorders, provide membrane stabilisation and suppress irritating or hypersensitive conditions of the inner ear sensory cells with sedative effects. ${ }^{11,12}$ The movement of the medicine injected into tympanic cavity towards inner ear through the round window makes this area a target for administering inner ear treatment. ${ }^{11,13}$ Intratympanic administration is a term used to define the process where a liquid medicine, mainly aminoglycosides and steroids, is given into the middle ear from the tympanic membrane, where the medicine is transferred into the inner ear through diffusion with the direct interaction of the round window membrane..$^{11,13,15}$

Therefore, the aim of the present study is the electrophysiological and ultrastructural investigation of intratympanic steroid activity in guinea pigs with experimentally induced cisplatin ototoxicity.

\section{MATERIALS AND METHODS}

\section{Animals}

This study was approved by the Animal Experiments Local Ethics Committee (protocol number 2007/079), Trakya University, Turkey. Sixteen healthy young-adult (age, 4-6 months) pigmented guinea pigs (weight, 600-900 g; gender, male) with normal auropalpebral reflex were included in the study. All animals underwent bilateral otoscopic examination and audiologic evaluation including $1000 \mathrm{~Hz}$ probe-tone tympanometry and auditory brainstem response (ABR) test. Baseline ABR measurement was performed 1 day before the experiment and 3 days after a single dose of cispl- 
atin administration. ${ }^{18-20}$ Animals were placed in a sound-isolated chamber. All measurements were performed under general anaesthesia. Guinea pigs were anaesthetised with IM injection of Ketamine (40 mg/kg; Ketalar ampoule, Pfizer, Istanbul) and Xylazine $(10 \mathrm{mg} / \mathrm{kg}$; Rhompun vial, Bayer, Istanbul). Body temperature was maintained at $38^{\circ} \mathrm{C}$ with a warming blanket. Our study was performed in two stages: the electrophysiological stage, and the ultrastructural stage.

\section{Drug Administration}

In intratympanic injections 21 , methylprednisolone (250 mg/4mL, prednol-L, Mustafa Nevzat, Istanbul, Turkey) and physiological saline $(0.9 \% \mathrm{NaCl}$; Eczacibasi, Istanbul, Turkey) were administered to the postero-inferior quadrant of tympanic membrane with a volume of $\sim 0.1-0.2 \mathrm{~mL}$ (until the middle ear was filled). In intraperitoneal injections ${ }^{18,20}$, a single dose of cisplatin (Cisplatin Ebewe, Liba, Istanbul, Turkey) $16 \mathrm{mg} / \mathrm{kg} /$ day was applied to the guinea pigs.

\section{Electrophysiological Examination}

\section{Tympanometric recordings}

Probe tone was set at $1000 \mathrm{~Hz}$. The pump speed was $100 \mathrm{daPa} / \mathrm{sec}$. The pressure range of measurement was set to $+200 \mathrm{daPa}$ and $-200 \mathrm{daPa}$. Type "A" tympanograms (peak pressure was between $+100 \mathrm{daPa}$ and $-100 \mathrm{daPa}$ ) were accepted as normal.

\section{ABR Recordings}

The ABR responses were recorded by three silver needle electrodes, placed subdermally over the vertex (positive), the ipsilateral mastoid (negative) and the contralateral mastoid (ground/reference) of the guinea pig. Click stimuli were delivered through an E-A-R Tone 3A (Aearo Co, Indianapolis) insert earphone, and ABR was recorded by using BRA2-05/95 version 5.XX Danplex, Germany. The repetition rate was $10 / \mathrm{sec}$, and an average of 300 sweeps were recorded. The stimulus intensity was initially $80 \mathrm{~dB} \mathrm{nHL}$, followed by $10-\mathrm{dB}$

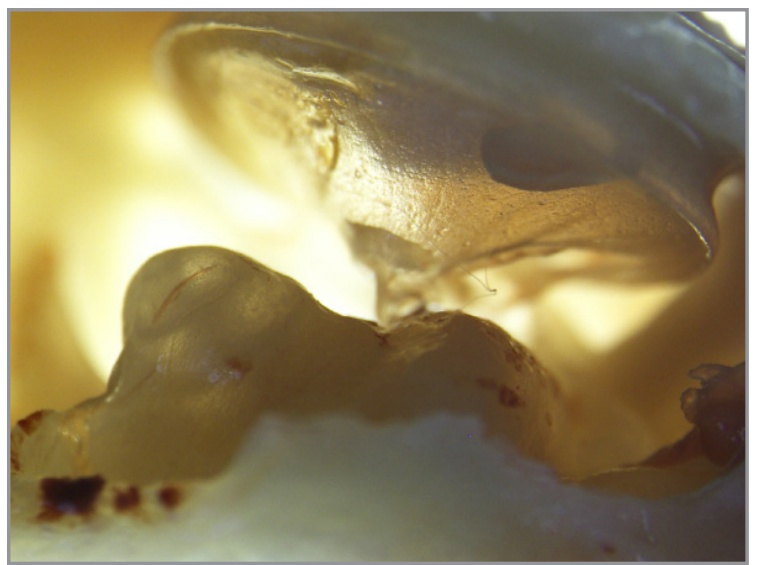

Figure 1. Following the dissection of temporal bone, otic capsule and cochlea were exposed (Magnification ratios: $15 \times 1.5$ $X 11.2)$.

decrements until waveforms were no longer present, thus determining the threshold of ABR. The ABR threshold was defined as the lowest $\mathrm{dB} \mathrm{nHL}$ level that produced a reliable peak III in the ABR waveforms. ABR recordings was repeated 3 days after the last dose of cisplatin in order to record the threshold shifts.

\section{Ultrastructural Examination}

After decapitation, temporal bones were stored with $2.5 \%$ glutaraldehyde in $0.1 \mathrm{M}$ phosphate buffer for 12 hours, and subsequently rinsed with 0.1 $\mathrm{mL} / \mathrm{L}$ phosphate buffer at $\mathrm{pH} 7.4$ for 1 day. After incubation in 0.1 M Na-EDTA (Sigma-Germany) decalcifier ( $\mathrm{pH}$ 7.4) for three weeks, tympanic bullae of temporal bones were opened, and the otic capsule of cochlea was removed (Figure 1) under stereo-microscopy (Olympus 1x71 S8 F3, Japan). Post-fixation of cochleas was performed with $1 \%$ osmium tetroxide in phosphate buffer for 1 hour, and then rinsed with phosphate buffer. The tissues were dehydrated through a graded series of ethanol. Tissues were then critical-point dried with amylacetate in a critical-point drier (CPD 010, Balzer Union, Liechtenstein) and sputter-coated with gold palladium in a Bio-Rad-SC502 (Hemel Hempstead, Herts, UK) sputter coater. The surface of the organ of Corti was examined and photographed with a scanning electron microscope (JEOL 6510LV, Tokyo, Japan). 


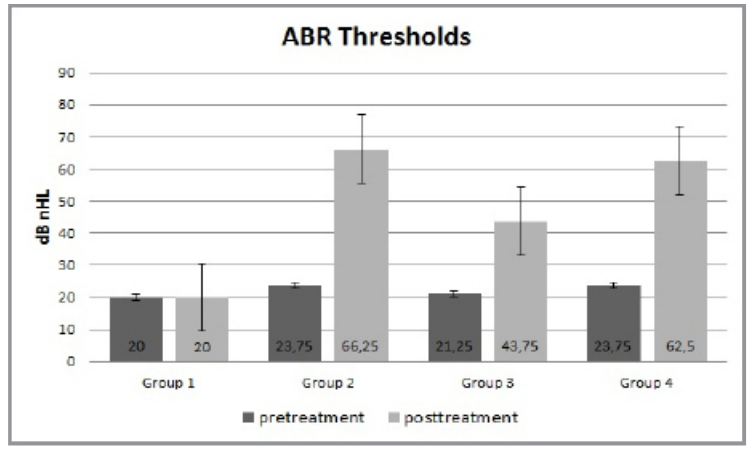

Figure 2. Thresholds of $A B R$ in all groups

\section{Study Protocol}

Sixteen ( $\mathrm{n}=32$ ears) guinea pigs with normal bilateral hearing were included. Guinea pigs were randomly divided into four groups and treated as follows:

Group 1 (Control group, $\mathrm{n}=8$ ears): No interference or drug administration was applied to the guinea pigs in this group. Group 2 (Cisplatin group, $\mathrm{n}=8$ ears): Intraperitoneal single-dose cisplatin 16 $\mathrm{mg} / \mathrm{kg} /$ day was administered to the guinea pigs in this group. Group 3 (Cisplatin/steroid group, $n=$ 8 ears): Intraperitoneal single-dose cisplatin 16 $\mathrm{mg} / \mathrm{kg} /$ day and intratympanic methylprednisolone $6.25 \mathrm{mg}(250 \mathrm{mg} / 4 \mathrm{~mL})$ were administered to the guinea pigs in this group. Group 4 (Cisplatin/physiological saline group, $\mathrm{n}=8$ ears): Intraperitoneal single-dose cisplatin $16 \mathrm{mg} / \mathrm{kg} /$ day and intratympanic physiological saline $(0.9 \% \mathrm{NaCl})$ were administered to the guinea pigs in this group. After the completion of electrophysiological measurements, guinea pigs were sacrificed to remove the cochleas for ultrastructural examination. The surface topography of the organ of Corti was examined and photographed with a scanning electron microscope (SEM). Relevant changes (site of degeneration) were evaluated ${ }^{22,23}$ as normal $\mathrm{OHCs}$ with intact $\mathrm{V}$ or $\mathrm{W}$-shaped stereocilia bundles and abnormal OHCs with damaged stereocilia or loss of the normal V or W-shaped stereocilia while total absence of stereocilia and rupture of the cuticular plate were considered as absent OHCs.

\section{Statistical Analysis}

Statistical analysis was performed after evaluating the conformity of normal distribution. As data

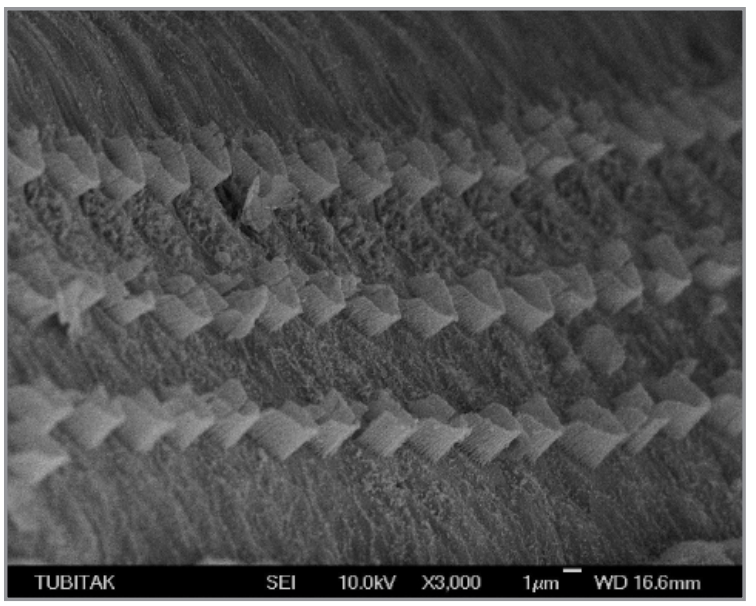

Figure 3. The surface of the organ of Corti in the control group: intact rows of outer hair stereocilia in the basal turn

were not convenient for parametric tests, intragroup comparisons were performed by means of Wilcoxon test, whereas intergroup comparisons were performed with the Mann-Whitney U test. Kruskal-Wallis test was applied for inter-group comparisons for more than two groups.

\section{RESULTS}

\section{Electrophysiology}

The ABR thresholds for the click stimulus were compared before and after drug administration in all groups (Figure 2). For the click stimulus, there was a significant $A B R$ threshold difference among the experimental groups (Mann-Whitney U test, $\mathrm{p}<$ 0.05 ) after drug administration. Group 3 had significantly lower ABR thresholds compared to Group 2 or Group 4 (Kruskal-Wallis test, $\mathrm{p}<0.05$ ), and Group 2 had significantly higher ABR thresholds compared to Group 1 or Group 3 (Kruskal-Wallis test, $\mathrm{p}<0.05$ ). There was no significant difference regarding ABR thresholds in the control group before and after drug administration (Wilcoxon test $\mathrm{p}>0.05)$.

\section{Analysis of SEM}

In the present study, we evaluated $\mathrm{OHC}$ degeneration in the surface anatomy of the organ of Corti in experimental and control groups. In Group 1 (control group), no morphology of $\mathrm{OHC}$ degeneration 


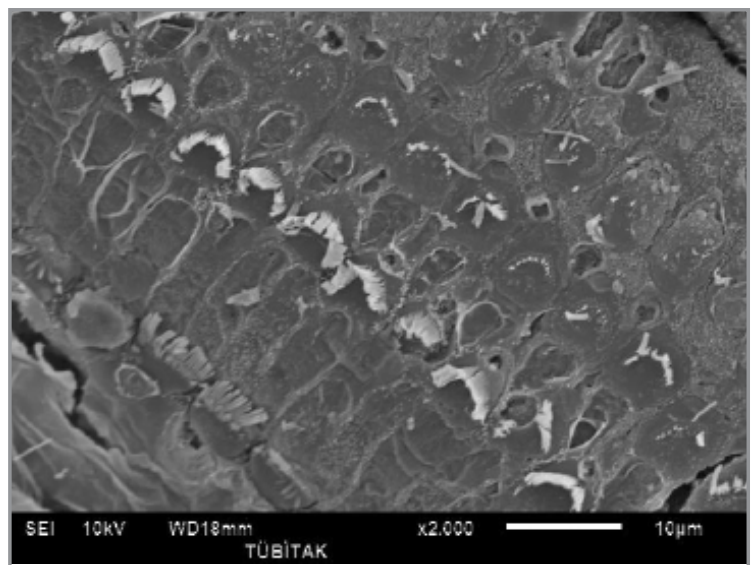

Figure 4. SEM micrograph depicting severe damage of all rows and rupture of cuticular plate of outer hair stereocilia in basal turn of the organ of Corti in the surface topography in the cisplatin group

was noted in the basal, middle and apex regions of cochlea (Figure 3). The SEM findings (Figure 4 and 5) in Group 2 (cisplatin) and Group 4 (cisplatin/physiological saline) revealed severe damage in OHCs at the basal and middle turns of the cochlea compared to Group 1 (control) and Group 3 (cisplatin/steroid) in which the cells exhibited deformed stereocilia or completely ruptured cuticular plates (Figure 4) in OHCs. In Group 3, OHCs with damaged stereocilia were observed only in the basal turns of cochlea (Figure 6). In Group 4, OHCs with severe damage were observed in the basal and middle turns of cochlea (Figure 5). When we compared Group 3 with Group 4 to evaluate the effect of intratympanic steroid administration,

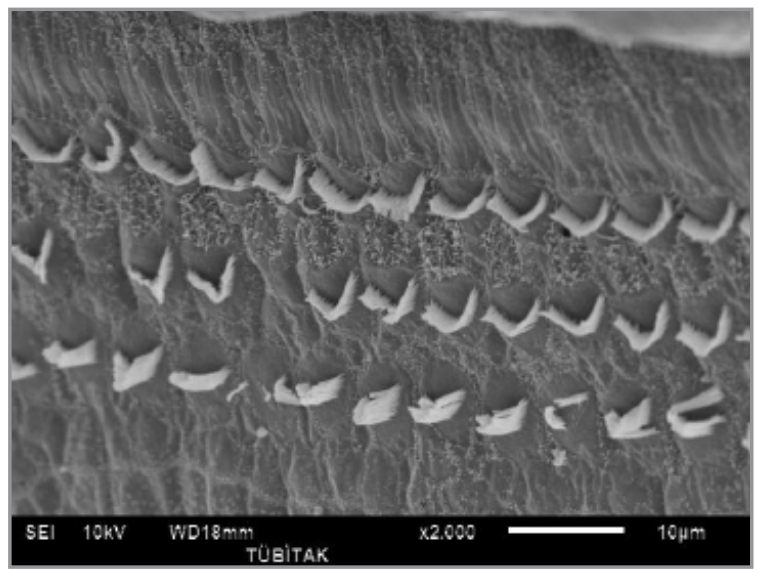

Figure 6. SEM micrograph in the steroid group: less damage in the outer hair stereocilia in the basal turn of the organ of Corti in surface examination

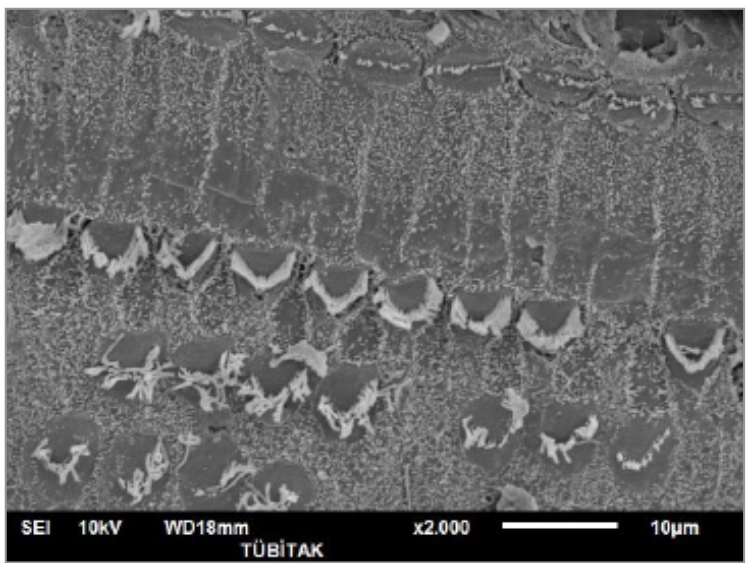

Figure 5. SEM micrograph: topographical examination of the organ of Corti in the physiological saline group reveals severe damage in outer hair stereocilia in the basal turn.

we found that Group 3 had less severely damaged OHCs, whereas Group 4 demonstrated severe loss of OHCs and total absence of stereocilia.

\section{DISCUSSION}

The ototoxic effect of cisplatin is characterised by irreversible, progressive, bilateral hearing loss at high frequencies accompanied by tinnitus. Factors that affect the incidence of ototoxicity include route of administration, cumulative dose, age, dietary factors, serum protein levels, genetic factors and history of cranial radiotherapy. ${ }^{3,4,7,24}$ In their analysis, Bokemeyer et al. ${ }^{25}$ investigated the ototoxicity incidence observed after treatment of testicular cancer with a cumulative cisplatin dose of $400 \mathrm{mg} /$ $\mathrm{m}^{2}$, and they diagnosed ototoxicity symptoms in 17 (20\%) out of the 86 cases included in their study. Although histopathology of cisplatin-induced ototoxicity is well-defined, the exact mechanism underlying the hearing loss remains unknown. The most striking histological features seen in cochleas of cisplatin-treated animals are the degeneration and loss of sensory cells in the organ of Corti. ${ }^{26}$ This loss typically starts at the first row of OHCs in the basal turn of cochlea, followed by the other OHC rows. ${ }^{21,26,27}$ With increasing doses or prolonged administration, it progresses towards more apically located cochlear turns and, eventually, to the single row of inner hair cells. ${ }^{26}$ Studies have shown that cisplatin causes an increase in auditory threshold due to the blockade of ion transduction 
channels and degeneration of sensory cells. ${ }^{18,28}$ Reactive oxygen species, which are thought to play a role in cisplatin-induced ototoxicity, are associated with the consumption of antioxidant enzymes. ${ }^{18,29}$ With the consumption of antioxidant enzymes; superoxide, hydrogen peroxide and toxic lipids result in calcium penetration into cochlear cells, triggering apoptosis. ${ }^{28-30}$

Several studies have been performed to prevent cisplatin-induced ototoxicity. In an experimental study where intraperitoneal cisplatin $16 \mathrm{mg} / \mathrm{kg}$ was administered to rats, Rybak et al. ${ }^{18}$ used diethyldithiocarbamate, 4-methylbenzoic acid, ebselen and lipoic acid as protective agents, and measured auditory brainstem response in each group before and 3 days after the treatment. Based on the cisplatin dose and occurrence of ototoxic effect 26 in previous studies ${ }^{18-20}$, ABR measurements were performed after Day 3. The group receiving cisplatin was found to have significant ABR threshold shifts while animals receiving protective agents had preserved ABR thresholds. Wang et al. ${ }^{31}$ administered sodium thiosulphate, which has otoprotective effects during cisplatin administration in rats, as intracochlear perfusion at a clinically high therapeutic dose. While no degeneration was observed in outer hair cells in the organ of Corti in ultrastructural analyses or hearing loss in electrophysiological measurements, marked loss of hearing and outer hair cells was seen in the group receiving cisplatin. Nader et al. ${ }^{27}$ used intratympanic lactate as a protective agent for cisplatin ototoxicity. Intratympanic lactate offers significant partial protection against cisplatin-induced ototoxicity at mid-frequencies. In their study on albino guinea pigs, Yumusakhuylu et al. ${ }^{19}$ found a significant shift in ABR threshold resulting from the loss of OHCs in basal, middle and apical turns after the 3rd day of intraperitoneal treatment with cisplatin $10 \mathrm{mg} /$ $\mathrm{kg}$ /day (two days-12 h interval dose). In our study, the ABR threshold shift and $\mathrm{OHC}$ degeneration in the basal and middle turns of cochlea were observed particularly in the group receiving cisplatin. In an experimental model, $\mathrm{Li}$ et al. ${ }^{20}$ demonstrated that sodium salicylate provides protection against the ototoxic effects of cisplatin without decreasing the anti-tumour potency of cisplatin. In the same study, intraperitoneal sodium salicylate $100 \mathrm{mg} /$ $\mathrm{kg}$ /day was used for 5 days, and after the 2nd day, intraperitoneal cisplatin $16 \mathrm{mg} / \mathrm{kg} /$ day was administered to rats for 3 days, and the rats followed with auditory brainstem response were found to be protected from the ototoxic effect.

In experimental studies ${ }^{19,21,23}$, it was observed that the area damaged in cochlea after cisplatin administration was the organ of Corti accompanied by $\mathrm{OHC}$ loss, and even though this damage was more severe in the basal turn, it was observed in all turns of cochlea. Our SEM findings in the cisplatin group showed severe damage in the OHCs at the basal and middle turn of cochlea compared to the control group and the cisplatin/steroid group. In several experimental studies, protective agents against cisplatin ototoxicity have been used through systemic $^{19}$ or intratympanic ${ }^{21}$ routes. With the intratympanic method, the protective agent reaches inner ear directly and with a high concentration without affecting other organs, and systemic side effects are quite fewer. ${ }^{32}$

The use of intratympanic protective agents to prevent cisplatin-induced ototoxicity has been investigated in animal models, but most studies have focused on intratympanic glucocorticoids. ${ }^{11-13,15,21,27}$ The underlying reason of using corticosteroids may be the reduced inflammation by autoimmune dysfunction through the immune effects, or the direct effects on the inner ear neuroepithelium. ${ }^{11}$ Proposed mechanisms of action include the notion that steroids move through the round window, improve cellular oedema and metabolic disorders of the inner ear, provide membrane stabilisation and suppress irritative or hypersensitive conditions in sensory cells of the inner ear through sedative effects. ${ }^{11,12}$ In our study, in the groups that received intratympanic steroid injections and physiological saline in addition to the cisplatin dose, the ABR test and electrophysiological measurements to determine the ototoxic effects revealed that the threshold difference was lower in the steroid group compared to the cisplatin group and the cisplatin/ physiological saline group, and ultrastructural evaluations showed reduced degeneration in outer hair cells of the organ of Corti. Diffuse perilymph was shown with the topical administration of dexamethasone and methylprednisolone in the round window. ${ }^{33}$ Intratympanic administration to the inner ear provides higher steroid concentrations com- 
pared to intravenous or oral administration. Methylprednisolone had the highest concentration and was the most permanent agent in endolymph and perilymph among the three drugs analysed..$^{11,33,34} \mathrm{In}$ a study by Bird et al. comparing the effectiveness of intratympanic versus systemic steroid injections in patients with cochlear implants, perilymph and plasma methylprednisolone levels were looked at, and while methylprednisolone was 33 times higher in the perilymph of patients who received intratympanic injection, plasma methylprednisolone concentrations were 136 times lower compared to those who received systemic administration. 35 This study also supports the transition from experimental studies to clinical trials regarding the potential use of intratympanic steroid administration.

Results of our study have shown that cisplatin causes ototoxic damages which have an apparent degenerative effect, particularly on $\mathrm{OHC}$ stereocilia in the cochlea. Hair cell stereocilia are the receptors of cochlea which process and transform the sound in inner ear. Hair cell depolarisation occurs through the stereocilia. Degenerative changes result in an ion blockade by affecting the ion channels on stereocilia. With this ion blockade, there can be be no auditory nerve activation to generate the necessary action potential in hair cells. We observed this findings in our electrophysiological study, and we found further ABR threshold shift in the groups receiving cisplatin compared to the steroid group. We observed at the ultrastructural level that when intratympanic steroid was used as a protective agent along with cisplatin, there was less degeneration in hair cell stereocilia morphology, and our electrophysiological study also showed less threshold shift in ABR. In conclusion, we believe that intratympanic steroid administration has a protective effect against ototoxic damage caused by cisplatin treatment. However, our analysis consisted of only three days, and we are not sure whether this protective effect persists longer than three days.

\section{Acknowledgments:}

We are grateful to The Scientific and Technological Research Council of Turkey-Marmara Research Centre (TUBITAK-MAM), Gebze, Kocaeli, for their support with the SEM examination.
This study was presented as a oral presentation in the $34 . \mathrm{Na}$ tional Congress of Turkish Society for Otorhinolaryngology \& Head Neck Surgery, Antalya, Turkey (10-14 November 2012).

\section{REFERENCES}

1. Rybak LP. Vestibular and Auditory Ototoxicity. In: Otolaryngology Head \&Neck Surgery. Cummings CW, Flint PW, Haugley $\mathrm{BH}$, et al.,(eds). 4th edition PA: Elsevire-Mosby, 2005: 2933-2943.

2. Sedó-Cabezón L, Boadas-Vaello P, Soler-Martín C, Llorens J. Vestibular damage in chronic ototoxicity: a mini-review. Neurotoxicology 43: 21-27, 2014.

3. Rybak LP, Kanno H. Ototoxicity. In: Otorhinolaryngology Head and Neck Surgery. Ballenger JJ, Snow JB, (eds). 15th ed. PA, Williams\&Wilkins, 1996: 1102-1108.

4. Lebwohl D, Canetta R. Clinical development of platinum complexes in cancer therapy: an historical perspective and an update. Eur J Cancer 34: 1522-1534, 1998.

5. Safirstein R, Winston J, Goldstein M, et al. Cisplatin nephrotoxicity. Am J Kidney Dis 8: 356-367, 1986.

6. Singh G, Koropatnick J. Differential toxicity of cis and trans isomers of dichlorodiammineplatinum. J Biochem Toxicol 3: 223-233, 1988.

7. Rybak LP, Whitworth CA. Ototoxicity: therapeutic opportunities. Drug Discov Today 10:1313-1321, 2005.

8. Chirtes F, Albu S. Prevention and restoration of hearing loss associated with the use of cisplatin. Biomed Res Int 2014: 925485, 2014.

9. Schimer BP, Parker KL. Adrenocorticotropic hormone adrenocortical steroids and their senthetic analogs; inhibitors of the senthesis and actions of adrenocortical hormones. In: The pharmacological basis of therapeutics. Hardman JG, Gilman AG, Limbird LE (eds). 9th edition. New York, McGraw-Hill Companies, 1996: 1459-1485.

10. Chrousos GP, Margioris AN. Adrenocorticosteroids \& Adrenocortical antagonists. In: Basics and Clinical Pharmacology. Katzung BG (eds). 8th edition. San Francisco, McGraw-Hill companies, 2001: 660-678.

11. Lavigne P, Lavigne F, Saliba I. Intratympanic corticosteroids injections: a systematic review of literature. Eur Arch Otorhinolaryngol 273: 2271-2281, 2016.

12. Engmér BC, Videhult PP, Ekborn A, et al. Local treatment of the inner ear: a study of three different polymers aimed for middle ear administration. Acta Otolaryngol 135: 985-994, 2015.

13. Meyer T. Intratympanic treatment for tinnitus: A review. Noise\&Health 15: 83-90, 2013.

14. Nagura M, Iwasaki S, Wu R, et al. Effects of corticosteroid, contrast medium and ATP on focal microcirculatory disorders of the cochlea. Eur J Pharmacol 366: 47-53, 1999. 
15. Himeno C, Komeda M, Izumikawa M, et al. Intra-cochlear administration of dexamethasone attenuates aminoglycoside ototoxicity in the guinea pig. Hear Res 67: 61-70, 2002.

16. Park SK, Choi D, Russell P, et al. Protective effect of corticosteroid against the cytotoxicity of aminoglycoside otic drops on isolated cochlear outer hair cells. Laryngoscope 114: 768771, 2004.

17. Hargunani CA, Kempton JB, DeGagne JM, Trune DR. Intratympanic injection of dexamethasone: time course of inner ear distribution and conversion to its active form. Otol Neurotol 27: 564-569, 2006.

18. Rybak LP, Whitworth C, Somani S. Application of antioxidants and other agents to prevent cisplatin ototoxicity. Laryngoscope 109: 1740-174, 1999.

19. Yumusakhuylu AC, Yazici M, Sari M, et al. Protective role of resveratrol against cisplatin induced ototoxicity in guinea pigs. Int J Pediatr Otorhinolaryngol 76: 404-408, 2012.

20. Li G, Sha SH, Zotova E, et al. Salicylate protects hearing and kidney function from cisplatin toxicity without compromising its oncolytic action. Lab Invest 82: 585-596, 2002.

21. Özel HE, Özdogan F, Gürgen SG, et al. Comparison of the protective effects of intratympanic dexamethasone and methylprednisolone against cisplatin-induced ototoxicity. J Laryngol Otol 130: 225-34, 2016.

22. Poyrazoglu E, Gungor A, Ugur G, et al. Demonstration of the effects of ototopical ciproflokacin on cochlea with scanning electron microscopy: (Experimentally study). KBB ve Bas Boyun Cerrahisi Dergisi 5: 116-121, 1997. (Article in Turkish with an abstract in English).

23. Salehi P, Akinpelu OV, Waissbluth $S$, et al. Attenuation of cisplatin ototoxicity by otoprotective effects of nanoencapsulated curcumin and dexamethasone in a guinea pig model. Otol Neurotol 35: 1131-9, 2014.

24. Waissbluth S, Peleva E, Daniel SJ. Platinum-induced ototoxicity: a review of prevailing ototoxicity criteria. Eur Arch Otorhinolaryngol 274: 1187-1196, 2017.

25. Bokemeyer C, Berger CC, Hartmann JT. Analysis of risk factors for cisplatin induced ototoxicity in patients with testicular cancer. Br J Cancer 77: 1355-1362, 1998.

26. Campbell KC, Meech RP, Rybak LP, Hughes LF. D-Methionine protects against cisplatin damage to the stria vascularis. Hear Res 138: 13-28, 1999.

27. Nader ME, Theoret Y, Saliba I. The role of intratympanic lactate injection in the prevention of cisplatin-induced ototoxicity. Laryngoscope 120: 1208-1213, 2010.

28. Rybak LP, Whitworth CA, Mukherjea D, Ramkumar V. Mechanisms of cisplatin induced ototoxicity and prevention. Hear Res 226: 157-167, 2007.

29. Dehne N, Lautermann J, Petrat F, et al. Cisplatin ototoxicity: involvement of iron and enhanced formation of superoxide anion radicals. Toxicol Appl Pharmacol 174: 27-34, 2001.
30. Rybak LP, Husain K, Morris C, et al. Effect of protective agents against cisplatin ototoxicity. Am J Otol 21: 513-520. 2000.

31. Wang J, Lloyd Faulconbridge RV, Fetoni A, et al. Local application of sodium thiosulfate prevents cisplatin-induced hearing loss in the guinea pig. Neuropharmacology 45: 380-393, 2003.

32. Light LP, Silverstein H. Transtympanic perfusion: indications and limitations. Curr Opin Otolaryngol Head Neck Surg 11: 334-339, 2003.

33. Yang J, Wu H, Zhang P, et al. The pharmacokinetic profiles of dexamethasone and methylprednisolone concentration in perilymph and plazma following systemic and local administration. Acta Otolaryngol 128: 496-504, 2008.

34. Parnes LS, Sun AH, Freeman DJ. Corticosteroid pharmacokinetics in the inner ear fluids: An animal study followed by clinical application. Laryngoscope 109 (7 pt 2): 1-17, 1999.

35. Bird PA, Begg EJ, Zhang M, et al. Intratympanic versus intravenous delivery of methylprednisolone to cochlear perilymph. Otol Neurotol 28: 1124-1130, 2007.

\section{Correspondence:}

Dr. Abdullah TAŞ

Trakya Üniversitesi Tip Fakültesi

Kulak Burun Bogaz Anabilim Dali

22030 EDIRNE / TURKIYE

Tel: +90 (284) 23576 42-1230

Fax: +90 (284) 2126107

e-mail: abdullahtas@trakya.edu.tr erdoganbulut@trakya.edu.tr 